\title{
THE "MICROMORPH" SOLAR CELL: EXTENDING A-SI:H TECHNOLOGY TOWARDS THIN FILM CRYSTALLINE SILICON
}

\author{
D. Fischer, S. Dubail, J. A. Anna Selvan, N. Pellaton Vaucher, R. Platz, Ch. Hof, U. Kroll, J. Meier, \\ P. Torres, H. Keppner, N. Wyrsch, M. Goetz, A. Shah, K.-D.Ufert* \\ Institut de Microtechnique, Université de Neuchâtel, Rue Breguet 2, 2000 Neuchâtel, Switzerland \\ *Siemens Solar, Frankfurter Ring, 80000 München, Germany
}

\begin{abstract}
Recent progress of solar cells based on plasma deposited hydrogenated microcrystalline silicon ( $\mu \mathrm{c}-$

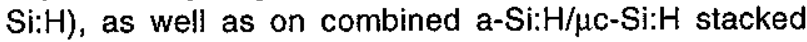
"micromorph" solar cells is reported. $\mu \mathrm{c}-\mathrm{Si}: \mathrm{H} \mathrm{p-i-n} \mathrm{cells}$ with a thickness of $3.6 \mu \mathrm{m}$, deposited with the use of a gas-purifier, are shown to have a short-circuit current of over $25 \mathrm{~mA} / \mathrm{cm}^{2}$, and a stable efficiency of $7.7 \%$. a-Si:H/ $\mu \mathrm{c}-\mathrm{Si}: \mathrm{H}$ tandem cells with $13 \%$ initial, and with $10 \%$ degraded state efficiency are also demonstrated. In addition, methods to further increase the efficiency of combined a-Si:H/ $\mathrm{Cc}-\mathrm{Si}: \mathrm{H}$ solar cells are discussed. This includes the introduction of a $\mathrm{ZnO}$ reflector layer between a-Si:H and $\mu \mathrm{c}-\mathrm{Si}: \mathrm{H}$ component cells, a new concept of which first experimental results are given.
\end{abstract}

\section{Introduction}

While the efficiency of a-Si:H based solar cells continues to increase incrementally through multiple technological refinements, it is agreed that a fundamentally new approach must be put at work to achieve a further substantial performance gain [1]. In this connection we present a radically new type of tandem solar cell that employs, in addition to a-Si:H top cells, infrared sensitive microcrystalline silicon ( $\mu \mathrm{c}-\mathrm{Si}: \mathrm{H}$ ) bottom cells. The high efficiency potential of this new tandem cell arises from the fact that a-Si:H and $\mu \mathrm{c}-\mathrm{Si}: \mathrm{H}$, with optical gaps of $1.7 \mathrm{eV}$ and $1 \mathrm{eV}$, respectively, are sufficiently wide spaced over the solar spectrum to create a powerful tandem-effect [2]. Furthermore, $\mu \mathrm{c}-\mathrm{Si}: \mathrm{H}$ cells show no light-induced degradation, which is particularly beneficial as they replace the generally less stable bottoms cells of pure amorphous stacked cells.

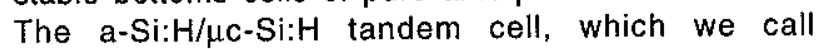
"micromorph" cell, offers thus a realistic potential to overcome the present efficiency limits of pure amorphous technology. The fabrication process of $\mu \mathrm{c}-\mathrm{Si}: \mathrm{H}$ is identical to that of amorphous silicon. Monolithic 2terminal micromorph tandem cells can thus be fabricated entirely by plasma CVD, in the same way as a-Si:H stacked cells. Consequently, the advantages of amorphous silicon manufacturing technology are fully maintained (low-cost substrates, large area deposition, low temperature processing). This must be kept in mind when comparing the micromorph cell to other forms of thin film crystalline cells [3], or other approaches to realize a-Si:H/crystalline silicon tandem cells [2].

\section{Microcrystalline $p-i-n$ solar cells}

Hydrogenated microcrystalline silicon $(\mu \mathrm{c}-\mathrm{Si}: \mathrm{H})$ is prepared by plasma CVD from hydrogen-diluted silane. Growth of $\mu \mathrm{c}-\mathrm{Si}: \mathrm{H}$ does not require any pre-orientation through the substrate, and takes place at a substrate temperature of about $200^{\circ} \mathrm{C}$. This makes it possible to use substrate materials like glass or plastic, or to deposit $\mu \mathrm{c}-\mathrm{Si} \mathrm{H}$ directly onto a-Si:H top cells, as required for the fabrication of monolithic tandem structures (see below).

In the present work $\mu \mathrm{c}-\mathrm{Si}: \mathrm{H}$ is deposited by using plasma excitation frequencies in the Very High Frequency (VHF) range. The use of VHF frequency deposition has been shown to favor the growth rate and the grain size of $\mu \mathrm{c}-\mathrm{Si}: \mathrm{H}$ as compared to material obtained by the standard RF discharge [4]. In the present work, for the deposition of $\mu \mathrm{c}$-Si:H i-layers a frequency of $110 \mathrm{MHz}$ is employed. The ratio of hydrogen to silane in

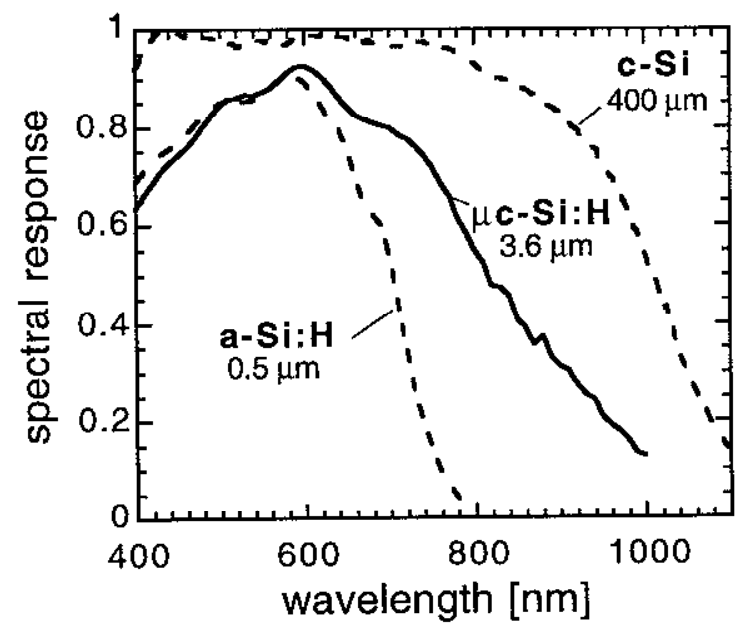

Fig. 1. Spectral response of a $\mu \mathrm{c}-\mathrm{Si}: \mathrm{H}$ p-i-n solar cell, compared to typical response of an a-Si:H p-i-n solar cell, and of a crystalline silicon wafer-based solar cell (c-Si). 
the feed gas is $40: 1$, the deposition rate is $1.2 \AA / s$.

The optical absorption of VHF-GD deposited $\mu \mathrm{c}-\mathrm{Si}: \mathrm{H}$ is similar to that of crystalline silicon (c-Si). An energy gap of about $1 \mathrm{eV}$ has been determined [5], with the remaining sub-bandgap absorption being rather low. Interestingly, the absorption of $\mu \mathrm{c}-\mathrm{Si}: \mathrm{H}$ at energies above the band-gap is somewhat enhanced over that of c-Si. The physical explanation for this phenomenon is still a matter of debate [5]. It remains to be seen to what exact extent this increased absorption quantitatively contributes to the photovoltaic performance of $\mu \mathrm{c}-\mathrm{Si}: \mathrm{H}$ cells.

In Fig. 1, the long-wavelength response of the $\mu \mathrm{c}-\mathrm{Si}: \mathrm{H} \mathrm{p}-\mathrm{i}-\mathrm{n}$ cells is seen to decrease in a constant slope towards the infrared range. The response extending beyond $1000 \mathrm{~nm}$ corroborates the finding of an effective optical gap of about $1 \mathrm{eV}$. The maximal photo-generated current so far achieved is of $25.4 \mathrm{mAlcm}^{2}$ in a $3.6 \mu \mathrm{m}$ thick p-i-n cell deposited on textured $\mathrm{SnO}_{2}$ substrate (Asahi U-type), with a textured $\mathrm{ZnO} / \mathrm{Ag}$ back contact (Fig. 1). Regarding the overall photocurrent potential of $\mu \mathrm{c}-\mathrm{Si}: \mathrm{H}$, the flatness of the long wavelength response indicates that even more current could be generated by either increasing the i-layer thickness, or by a yet improved light-trapping.

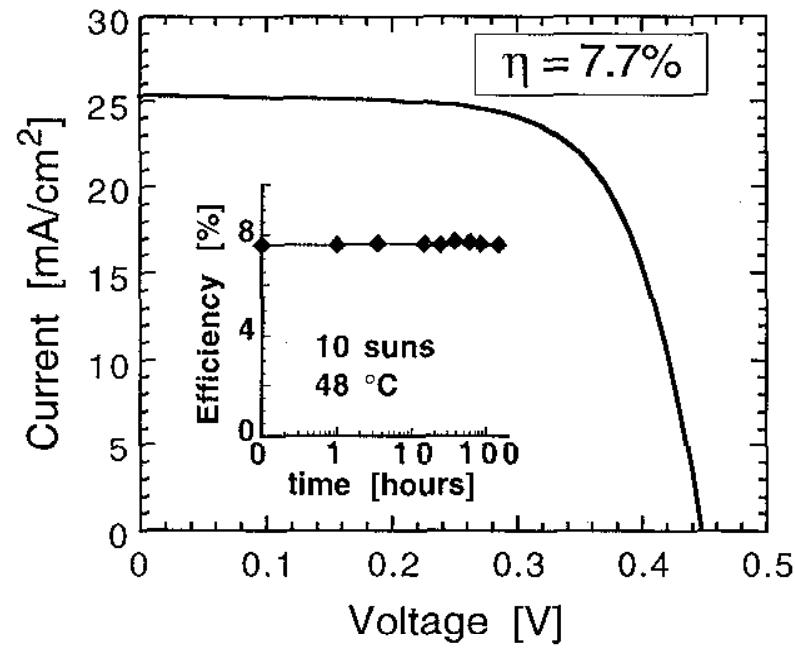

Fig. 2. JV characteristics of a $3.6 \mu \mathrm{m}$ thick $\mu \mathrm{c}-\mathrm{Si}: \mathrm{H}$ p-i-n solar cell under $A M 1.5 / 100 \mathrm{~mW} / \mathrm{cm}^{2}$ conditions $\left(V_{O C}=448 \mathrm{mV}, J_{S C}=25.4 \mathrm{~mA} / \mathrm{cm}^{2}, F F=0.68, \eta=7.7 \%\right.$ ). Inset: efficiency during high intensity light-soaking.

In the past, a sufficient photocarrier collection was only achieved with i-layer compensation by low-level $\mathrm{B}_{2} \mathrm{H}_{6}$ doping $[6,7]$. Recently, it was shown that this technologically difficult compensation can be omitted if the plasma feed gas is cleaned by a oxygen-suppressing gas-purifier [8,9]. By employing this technique, the i-layer thickness could be extended to $3.6 \mu \mathrm{m}$ without compromising the photocurrent collection, whereas with the compensation method, the i-layer thickness had been limited to about $2 \mu \mathrm{m}$. Fig. 2 shows the $\mathrm{JV}$-curve of the cell with the highest efficiency $(7.7 \%)$ obtained so far.
The spectral response of this cell is given in Fig. 1 . Similar to previous results, this device proved to be entirely stable under light-soaking (Fig. 2, inset).

\section{Micromorph tandem cells}

As mentioned above, it is the combination of $\mu \mathrm{c}-\mathrm{Si}: \mathrm{H}$ bottom cells with a-Si:H top cells in a monolithic stacked cell that bears the actual potential for high efficiencies. $\mu \mathrm{c}-\mathrm{Si}: \mathrm{H}$ cells of the type shown in Fig. 2 were deposited onto a-Si:H p-i-n top cells. Current matching was obtained at around $13 \mathrm{~mA} / \mathrm{cm}^{2}$ with an a-Si:H top cell i-layer thickness of $0.3 \mu \mathrm{m}$ thickness. With this combination, an (initial) efficiency of $13.1 \%$ was obtained (Fig. 3).

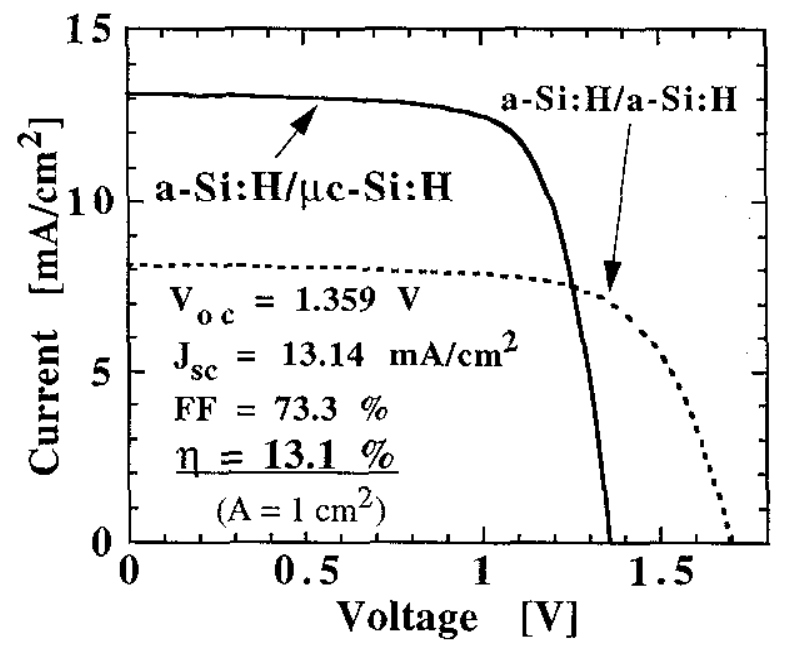

Fig. 3. JV-characteristics under $A M 1.5 / 100 \mathrm{~mW} / \mathrm{cm}^{2}$ conditions for the micromorph tandem cell, in comparison with a conventional a-Si:H/a-Si:H tandem cell.

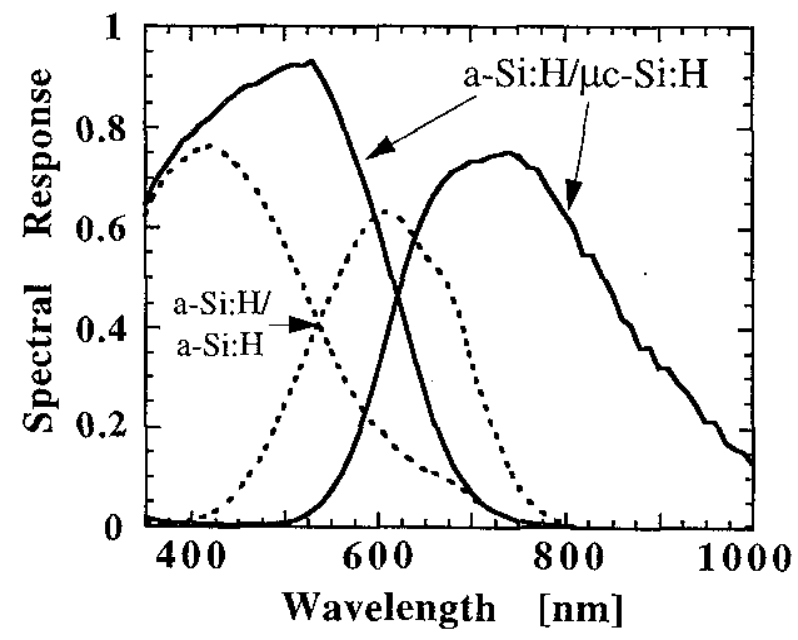

Fig. 4. Spectral response of the micromorph tandem cell of Fig. 3 , in comparison with a standard amorphous double stacked cell. The $\mathrm{J}_{\mathrm{Sc}}$-values for AM1.5 conditions are, for the top $13.1 \mathrm{~mA} / \mathrm{cm}^{2}$, and for the bottom cell, $13.8 \mathrm{~mA} / \mathrm{cm}^{2}$. 
No voltage loss occurs in the stacked device, considering that a voltage of $0.9 \mathrm{~V}$ and of $0.45 \mathrm{~V}$ is typically obtained in the corresponding single-junction a-Si:H and $\mu \mathrm{c}-\mathrm{Si} \mathrm{H}$ cells, respectively. Together with a good fillactor, these results confirm the complete compatibility of the a-Si:H cell and the $\mu \mathrm{c}-\mathrm{Si}: \mathrm{H}$ cell in the monolithic tandem cell configuration.

Due to the incorporation of an a-Si:H top cell, the micromorph tandem cell is obviously subject to SWE-type degradation behavior. At the present state of development, the a-Si:H top cell produces $2 / 3$ of the total power of the tandem cell, thus dominates the performance of the whole device. Correspondingly, the stability of the a-Si:H top cell becomes a critical issue in the development of the micromorph tandem cells.

To improve the tandem cell stability, we applied $\mathrm{H}_{2}$ dilution and low deposition temperature to the a-Si:H cell i-layer. This measure has been shown to improve the stability of single junction a-Si:H p-i-n cells $[10,11]$. Further we reduced the i-layer thickness of the top cell to $0.21 \mu \mathrm{m}$, leading to tandem cell that is current limited by the top cell at $11.5 \mathrm{~mA} / \mathrm{cm}^{2}\left(\mathrm{H}_{2}\right.$-dilution additionally contributes to a reduced top cell current, as the absorption of the diluted i-layer material is reduced [11]). This tandem cell, that has an initial efficiency of $11.4 \%$, shows a relative degradation of $-12 \%$ (see Table 1 ).

\begin{tabular}{lccccc}
\hline status & $\mathrm{J}_{\mathrm{a}-\mathrm{Si}}$ & $\mathrm{J}_{\mu \mathrm{c}-\mathrm{Si}}$ & $\mathrm{V}_{\mathrm{oc}}$ & $\mathrm{FF}$ & $\eta$ \\
& $\mathrm{mA} / \mathrm{cm}^{2}$ & $\mathrm{~mA} / \mathrm{cm}^{2}$ & $\mathrm{~V}$ & & $\%$ \\
\hline initial & 11.5 & 14.0 & 1.34 & 0.73 & 11.4 \\
light-soaked & 11.2 & 14.0 & 1.33 & 0.67 & 10.0 \\
$\left(145 \mathrm{~h}, 1\right.$ sun, $\left.48^{\circ} \mathrm{C}\right)$ & & & & \\
\hline
\end{tabular}

Table 1. Light-soaking behavior of a top-cell limited micromorph tandem cell. The top cell is deposited at $180^{\circ} \mathrm{C}$, with a graded hydrogen dilution in the i-layer; the $\mathrm{i}$-layer thickness is $0.21 \mu \mathrm{m}$.

\section{Scope of further improvements}

To become advantageous over pure a-Si:H/a-SiGe:H solar cell technology, the micromorph solar cells should show a clear efficiency superiority. The target is to reach at least $12 \%$ stable efficiency. In the following we will discuss how this target could be reached in the future.

The most direct improvement would result from an increase of the $\mathrm{V}_{\mathrm{oc}}$-values of the $\mu \mathrm{c}-\mathrm{Si}: \mathrm{H}$ bottom cell (Fig. 5). The energy gap of $\mu \mathrm{c}-\mathrm{Si}: \mathrm{H}$ of $1 \mathrm{eV}$ limits a priori the $\mathrm{V}_{\mathrm{oc}}$-values to a level below that of a-Si:H. However, it has been shown that $\theta . g$. with thin, solid phase crystallized silicon cells open circuit voltages of $550 \mathrm{mV}$ are possible [3]. Fig. 6 shows that with such a $V_{o c}$ in the $\mu \mathrm{c}-\mathrm{Si}: \mathrm{H}$ bottom cell the efficiency of the tandem cell would increase by about $1 \%$ absolute. However, at present it is not clear by what the $\mathrm{V}_{O C}$ of $\mu \mathrm{c}-\mathrm{Si}: \mathrm{H} \mathrm{p}-\mathrm{i}-\mathrm{n}$ cells is limited, and how it could be improved.

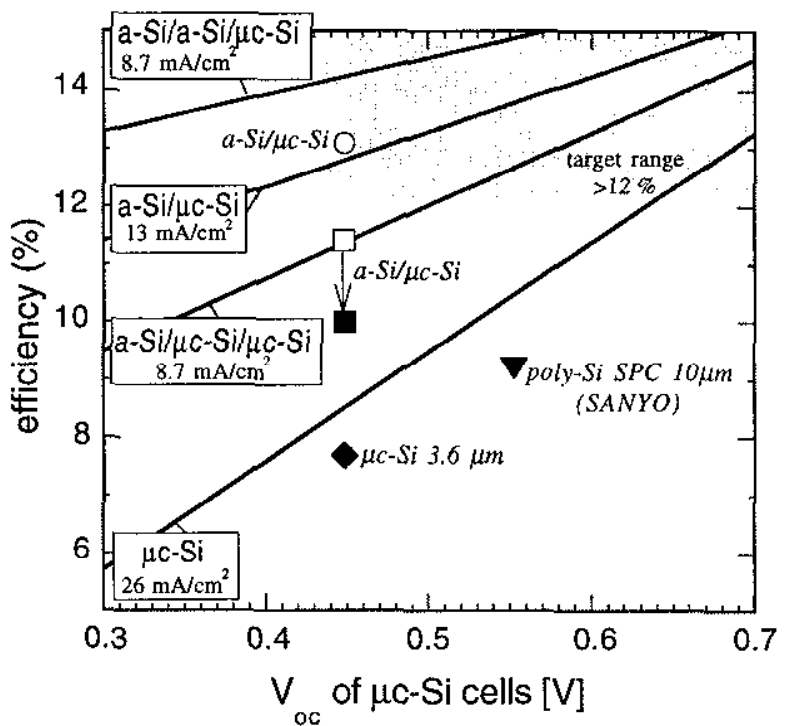

Fig. 5. Projected efficiencies of single-junction $\mu \mathrm{c}-\mathrm{Si}: \mathrm{H}$, and micromorph stacked cells as a function of the $V_{O C}$ of the $\mu \mathrm{c}-\mathrm{Si}: \mathrm{H}$ solar cells, assuming a total current of $26 \mathrm{~mA} / \mathrm{cm}^{2}$, a fill factor of $73 \%$, and a $V_{o c}$ of $900 \mathrm{mV}$ for the a-Si:H cells (lines). For comparison, efficiencies of various realized solar cells are indicated (symbols): ( $)$ : $\mu \mathrm{c}-\mathrm{Si}$ single cell, $25.4 \mathrm{~mA} / \mathrm{cm}^{2}$ (Fig. 1/2); ( $)$ ): p-n cell by solid phase crystallization of a-Si:H on metal, $25 \mathrm{~mA} / \mathrm{cm}^{2}$ [3]; (O): a-Si/ $\mu \mathrm{c}-\mathrm{Si}, 13.1 \mathrm{~mA} / \mathrm{cm}^{2}$ (Fig. 3), initial state; $(\square, \square)$ : a-Si/ $\mu \mathrm{c}-S i$ tandem cell, $11.5 \mathrm{~mA} / \mathrm{cm}^{2}$ (Table 1 ), before and after degradation.

As mentioned above, the a-Si:H power contribution and its stability play a crucial role in the micromorph cell. The task is here is to combine the required current generation with the best possible stability.

Fig. 5 shows that the highest efficiencies could result from a-Si:H/a-Si:H/ $/ \mathrm{c}-\mathrm{Si} \mathrm{H}$ micromorph triple cells, as in that case $2 / 3$ of the absorbed photons would be converted in high voltage level a-Si:H cells. With a total photocurrent of $26 \mathrm{~mA} / \mathrm{cm}^{2}$, the matched current would be of $8.7 \mathrm{~mA} / \mathrm{cm}^{2}$. Our experiments showed that an a-Si:H middle cell is by far not capable to generate as much current [7]. This observation was already made in a-Si:H/a-Si:H/a-SiGe triple cells [12], at an even lower current level. An a-SiGe:H middle cell, and/or a $\mathrm{ZnO}$ intermediate reflector (see below) could in the future still lead to a viable a-Si:H/a-Si(Ge?):H/ $/ \mathrm{c}-\mathrm{Si}: \mathrm{H}$ triple cell.

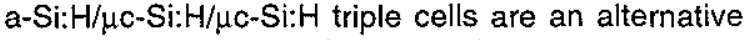
design option. Their attractiveness is in the fact that one can expect an almost negligible light-induced degradation, because only one very thin a-Si:H top cell would be involved (possibly less than $0.1 \mu \mathrm{m}$ thick). This option becomes particularly interesting with increasing $\mathrm{V}_{\mathrm{oc}}{ }^{-}$ values of the $\mu \mathrm{c}-\mathrm{Si}: \mathrm{H}$ component cells (Fig. 5).

The basic a-Si/ $/ \mathrm{c}-\mathrm{Si}$ double stacked tandem cell itself could be improved by the application of a novel, intermediate $\mathrm{ZnO}$ reflector layer between a-Si:H top and 
$\mathrm{c}$ - $\mathrm{Si}: \mathrm{H}$ bottom cells. With such an intermediate $\mathrm{ZnO}$ layer, a partial reflection of light back into the a-Si:H top cell can be achieved. The reflection effect results from the difference in index of refraction between the $\mathrm{ZnO}$ layer $(n=2)$ and the surrounding silicon layers. It is important to note that the $\mathrm{ZnO}$ layer has an only optical function, and that the cell remains a monolithic, 2terminal tandem cell (the $\mathrm{ZnO}$ reflector layer must just be sufficiently conductive to support the vertical device current). Fig. 6 shows the measured spectral response in a micromorph tandem cell as a function of $\mathrm{ZnO}$ layer thickness between a-Si:H top and $\mu \mathrm{c}-\mathrm{Si}: \mathrm{H}$ bottom cells. Unlike expected, already relatively thin $(<100 \mathrm{~nm}) \mathrm{ZnO}$ layers result in substantial reflection in the wavelength range of interest $(500$ to $700 \mathrm{~nm})$. This indicates that scattering effects due to the textured TCO substrate, and a resulting total reflection at the a-Si:H/ZnO interface, strongly contribute to the reflection effect.

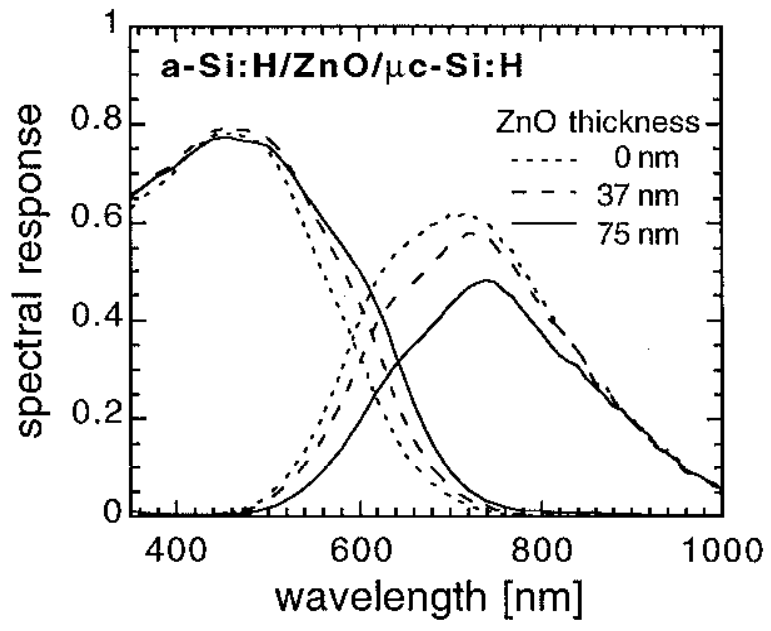

Fig. 6. Spectral response of a micromorph tandem cell with $0.09 \mu \mathrm{m}$ thick a-Si:H top cell and a $3.4 \mu \mathrm{m}$ thick $\mu \mathrm{c}$ $\mathrm{Si} H \mathrm{H}$ bottom cell, with and without $\mathrm{ZnO}$ intermediate reflector layers. Current densities are given in Table 2.

\begin{tabular}{cccc}
\hline ZnO layer & $\begin{array}{c}J_{\mathrm{a}-S i} \\
\mathrm{~mA} / \mathrm{cm}^{2}\end{array}$ & $\begin{array}{c}\mathrm{J}_{\mu \mathrm{c}-\mathrm{Si}} \\
\mathrm{mA} / \mathrm{cm}^{2}\end{array}$ & $\begin{array}{c}J_{\text {total }} \\
\mathrm{mA} / \mathrm{cm}^{2}\end{array}$ \\
\hline 0 & 9.5 & 11.6 & 21.1 \\
37 & 10.7 & 10.4 & 21.1 \\
75 & 11.3 & 8.3 & 19.6 \\
\hline
\end{tabular}

Table 2. Current densities of micromorph tandem cells as a function of $\mathrm{ZnO}$ reflector layers between top and bottom cells (same cells as Fig. 6) .

Most encouraging is the fact that our experimental results show for some cases almost negligible losses in the total absorbed current (Fig. 6, $37 \mathrm{~nm}$ ). This means that a suitable $\mathrm{ZnO}$-layer can achieve in fact a loss-free re-distribution of light absorption towards the a-Si:H topcell. This could enable a reduced a-Si:H top cell thickness, leading to an improved stability of the micromorph tandem cell without compromising initial performance. A ZnO reflector layer could further also help to overcome the problem of the middle-cell current in

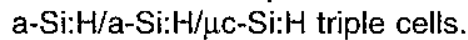

\section{CONCLUSIONS}

Microcrystalline silicon $p-i-n$ cells, as deposited by VHF-plasma deposition in a similar way as a-Si:H solar cells, are shown to have an extended infrared response, and to be entirely stable under light-soaking. The application of gas-purification enabled an extension of the i-layer thickness to up to $3.6 \mu \mathrm{m}$, leading to a current density of over $25 \mathrm{~mA} / \mathrm{cm}^{2}$, and a stable efficiency of $7.7 \%$. The most interesting potential of this new type of solar cell lies in its combination with an amorphous silicon top cell in a monolithic tandem solar cell. The high efficiency potential of this new "micromorph"-tandem cells is confirmed by $13 \%$ initial, and $10 \%$ stable efficiency.

In the optimisation of the micromorph tandem solar cell, the a-Si:H top cell must fulfill the conflicting needs of sufficient current generation on the one side, and maximal stability on the other side. In this connection, a-Si:H/ $/ \mathrm{c}-\mathrm{Si}: \mathrm{H} / \mu \mathrm{c}-\mathrm{Si}: \mathrm{H}$ triple cells are proposed to improve the stability of micromorph celis. Alternatively, the introduction of a $\mathrm{ZnO}$ reflector layer between a-Si:H top and $\mu \mathrm{c}-\mathrm{Si}: \mathrm{H}$ bottom cells is shown to increase the light-absorption in the a-Si:H top cell. This could in the future enable a thickness reduction of the a-Si:H top cells

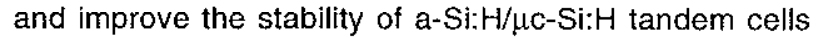
accordingly.

While different schemes thus have a realistic potential to reach the target efficiency of $12 \%$, the severe problem of insufficient deposition rates of the $\mu \mathrm{c}-\mathrm{Si}: \mathrm{H}$ layers still remains to be solved.

\section{Acknowledgments}

This work was supported by the Swiss Federal Department of Energy BEW/OFEN, grant EF-REN (93)032

\section{References}

[1] K.Zweibel, Progress in Photovoltaic Research and Applications, Vol.3, No.5 (1995), p.279

[2] W. Ma et al, Proc.23rd IEEE PVS Conf.(1993), p.833

[3] T. Baba et al, Proc. 13th EC PVSEC (1995), p.1708

[4] F. Finger et al, Appl.Phys.Lett.65 (1994), p.2588

[5] N. Beck et al, 16th ICAS Proc.(1995), to be published in J. Non-Cryst. Solids.

[6] J. Meier et al, Proc. of 1st WCPEC (1994), p.409

[7] J. Meier et al, Proc. 13th EC PVSEC(1995) p.1445

[8] J. Meier et al, MRS Symp.Proc.420(1996), to be publ.

[9] P. Torres et al, submitted to Appl.Phys. Lett.

[10] J.Yang et al, MRS Symp.Proc.336 (1994), p.687

[11] R.Platz et al, MRS Symp.Proc.420(1996), to be publ.

[12] X.Xu et al, Proc.23rd IEEE PVS Conf.(1993), p.971 